\title{
BMJ Open Cost-effectiveness of nurse practitioners in primary and specialised ambulatory care: systematic review
}

Ruth Martin-Misener, ${ }^{1}$ Patricia Harbman, ${ }^{2,3}$ Faith Donald, ${ }^{4}$ Kim Reid, ${ }^{5}$ Kelley Kilpatrick, ${ }^{6}$ Nancy Carter, ${ }^{3}$ Denise Bryant-Lukosius, ${ }^{7}$ Sharon Kaasalainen, ${ }^{3}$ Deborah A Marshall, ${ }^{8}$ Renee Charbonneau-Smith, ${ }^{3}$ Alba DiCenso ${ }^{9}$

To cite: Martin-Misener $\mathrm{R}$, Harbman P, Donald F, et al. Cost-effectiveness of nurse practitioners in primary and specialised ambulatory care: systematic review. BMJ Open 2015;5:e007167.

doi:10.1136/bmjopen-2014007167

- Prepublication history and additional material is available. To view please visit the journal (http://dx.doi.org/ 10.1136/bmjopen-2014007167).

Received 10 November 2014 Revised 27 March 2015 Accepted 27 April 2015

CrossMark

For numbered affiliations see end of article.

Correspondence to Dr Ruth Martin-Misener; ruth.martin-misener@dal.ca

\section{ABSTRACT}

Objective: To determine the cost-effectiveness of nurse practitioners delivering primary and specialised ambulatory care.

Design: A systematic review of randomised controlled trials reported since 1980.

Data sources: 10 electronic bibliographic databases, handsearches, contact with authors, bibliographies and websites.

Included studies: Randomised controlled trials that evaluated nurse practitioners in alternative and complementary ambulatory care roles and reported health system outcomes.

Results: 11 trials were included. In four trials of alternative provider ambulatory primary care roles, nurse practitioners were equivalent to physicians in all but seven patient outcomes favouring nurse practitioner care and in all but four health system outcomes, one favouring nurse practitioner care and three favouring physician care. In a meta-analysis of two studies (2689 patients) with minimal heterogeneity and high-quality evidence, nurse practitioner care resulted in lower mean health services costs per consultation (mean difference: $-€ 6.41 ; 95 \% \mathrm{Cl}-€ 9.28$ to $-€ 3.55 ; p<0.0001)(2006$ euros). In two trials of alternative provider specialised ambulatory care roles, nurse practitioners were equivalent to physicians in all but three patient outcomes and one health system outcome favouring nurse practitioner care. In five trials of complementary provider specialised ambulatory care roles, 16 patient/provider outcomes favouring nurse practitioner plus usual care, and 16 were equivalent. Two health system outcomes favoured nurse practitioner plus usual care, four favoured usual care and 14 were equivalent. Four studies of complementary specialised ambulatory care compared costs, but only one assessed costs and outcomes jointly. Conclusions: Nurse practitioners in alternative provider ambulatory primary care roles have equivalent or better patient outcomes than comparators and are potentially cost-saving. Evidence for their cost-effectiveness in alternative provider specialised ambulatory care roles is promising, but limited by the few studies. While some evidence indicates nurse practitioners in complementary specialised ambulatory care roles improve patient outcomes, their cost-effectiveness requires further study.

\section{Strengths and limitations of this study}

- Our review used a comprehensive search strategy to identify relevant trials that evaluated formallytrained or licensed nurse practitioners delivering primary or specialised ambulatory care.

- The quality of the trials and individual outcomes was assessed using the Cochrane risk of bias criteria, Quality of Health Economic Studies (QHES) instrument and Grading of Recommendations, Assessment, Development and Evaluation (GRADE) system.

- Outcomes that were reported in more than one study were combined using meta-analysis; opportunities were limited because trials did not use common outcome measures, to facilitate the pooling of results.

- There is high-quality evidence that nurse practitioners in alternative provider ambulatory primary care roles are cost-effective with patient outcomes that are equivalent to or better than usual care and with lower costs; the evidence for their costeffectiveness in alternative provider specialised ambulatory care roles is promising, but limited by the small number of studies; it was not possible to draw conclusions about the cost-effectiveness of the complementary provider specialised ambulatory care role of nurse practitioners because of the generally low quality of evidence.

- Three trials of the nurse practitioner role in ambulatory primary care evaluated a narrow scope of the nurse practitioner role because the intervention was limited to a single visit with patients seeking same day consultations for common complaints.

\section{INTRODUCTION}

Ambulatory care encompasses a broad range of personal healthcare services that do not require an overnight hospital stay. ${ }^{1}$ This is the defining feature of ambulatory care, not the setting or type of service, both of which are quite varied. Settings can be community or hospital based. Services can include diagnosis, observation, monitoring, consultation, 
prevention, treatment, rehabilitation, and diagnostic, therapeutic or surgical procedures. This paper focuses on ambulatory primary care and ambulatory specialty care. We define the former as a full range of comprehensive services, including diagnosis and treatment of undifferentiated health problems longitudinally over time and the latter as focused services for a specific population with the same condition or need for specific services.

Improving the quality of ambulatory care services within a value for cost framework is a world-wide challenge. ${ }^{2-4}$ In response, new healthcare provider roles have been developed and existing roles adapted. Introduced in North America more than 50 years ago, nurse practitioners carry out a range of activities, some of which overlap with activities traditionally performed by physicians. ${ }^{5}$ The extent to which nurse practitioner roles are autonomous or supervised varies within ${ }^{6}$ and $\operatorname{across}^{5}$ countries, and their acceptance by physicians is inconsistent. ${ }^{7}$

Nurse practitioners function in alternative or complementary roles. ${ }^{8}$ In alternative roles nurse practitioners provide similar services to those for whom they are substituting, usually physicians, whereas in complementary roles nurse practitioners provide additional services that are intended to complement or extend existing services. Usually the health service aim of the former is to reduce cost or workload or to address workforce shortages, while for the latter it is to improve quality of care.

Research dating back to the $1970 \mathrm{~s}^{9}$ and in subsequent reviews ${ }^{10-13}$ has shown that nurse practitioners in either alternative or complementary roles provide high-quality patient care that results in high patient and provider satisfaction. What is unclear is whether or not nurse practitioner care is cost-effective. ${ }^{12}$ This information along with information about the influence of nurse practitioner care on patient and provider outcomes is needed for decision-making to achieve the triple aim of better health, better care and better value. ${ }^{14}$

The purpose of this paper is to report a systematic review of 11 randomised controlled trials that assessed the costeffectiveness of nurse practitioners in primary and specialised ambulatory care. These trials are part of a larger systematic review of 43 trials examining the cost-effectiveness of advanced practice nurses in various settings.

\section{METHODS}

\section{Selection of studies}

We included trials evaluating nurse practitioners working in alternative or complementary provider roles in primary or specialised ambulatory care. We required papers to specify, or the author to confirm, that nurse practitioners had completed a formal nurse practitioner education programme and/or were licensed as nurse practitioners. Studies were excluded if the control group was exposed to a nurse practitioner or the nurse practitioner contribution to an intervention could not be isolated from other healthcare providers on the team.
The primary outcomes of interest in this review of nurse practitioner cost-effectiveness were objective measures of health system utilisation. These included use of services (eg, length of consultation, referrals, emergency department visits, hospitalisations), costs of healthcare (eg, personnel costs, medications, family costs) and health resource use (eg, diagnostic tests). Since health system utilisation must be considered in the context of patient and provider outcomes, additional primary outcomes of interest were patient health status, quality of life, and satisfaction, as well as provider outcomes such as quality of care and job satisfaction. Studies were excluded if they did not include a measure of health system utilisation.

\section{Identification of studies}

We searched for relevant published and unpublished trials reported from 1980 to July 2012 without restrictions on jurisdiction or language (figure 1). We searched 10 electronic bibliographic databases, handsearched key journals, reviewed reference lists of relevant papers, searched websites and contacted authors. We updated the database search by repeating it for the period from 31 July 2012 to 31 July 2013. More details about the search strategy and study protocol can be found elsewhere. ${ }^{15}$

After duplicates were removed, two-member teams independently screened titles and abstracts for relevance followed by full-text review of eligible papers. Discrepancies were resolved through discussion. A research assistant extracted data from each relevant study. Team members checked the accuracy of extractions and discrepancies were resolved through discussion leading to consensus. Findings from a single study reported in two or more papers were extracted as one study.

\section{Assessment of study quality}

Two researchers independently assessed the quality of studies for internal validity using a slightly modified version of the Cochrane risk of bias criteria $^{16}$ and resolved disagreements through discussion. Eight questions were each assigned a high, low or unclear risk of bias following which an overall risk of bias was assigned to the study as follows: low risk of bias (at risk in $0-1$ category), moderate risk of bias (at risk in 2-3 categories), high risk of bias (at risk in 4-6 categories), and very high risk of bias (at risk in 7-8 categories).

Using the Quality of Health Economic Studies instrument, ${ }^{17-20}$ two research assistants independently assessed each study for rigour of the economic analysis. Studies were stratified according to quartiles for extremely poor quality (0-24), poor quality (25-49), fair quality (50-74) and high quality (75-100). ${ }^{19}$

We evaluated the quality of the body of evidence for individual outcomes using the Grading of Recommendations Assessment, Development and Evaluation (GRADE) system ${ }^{21}$ and GRADEpro software. The quality of evidence was considered 'high level' until downgraded based on 


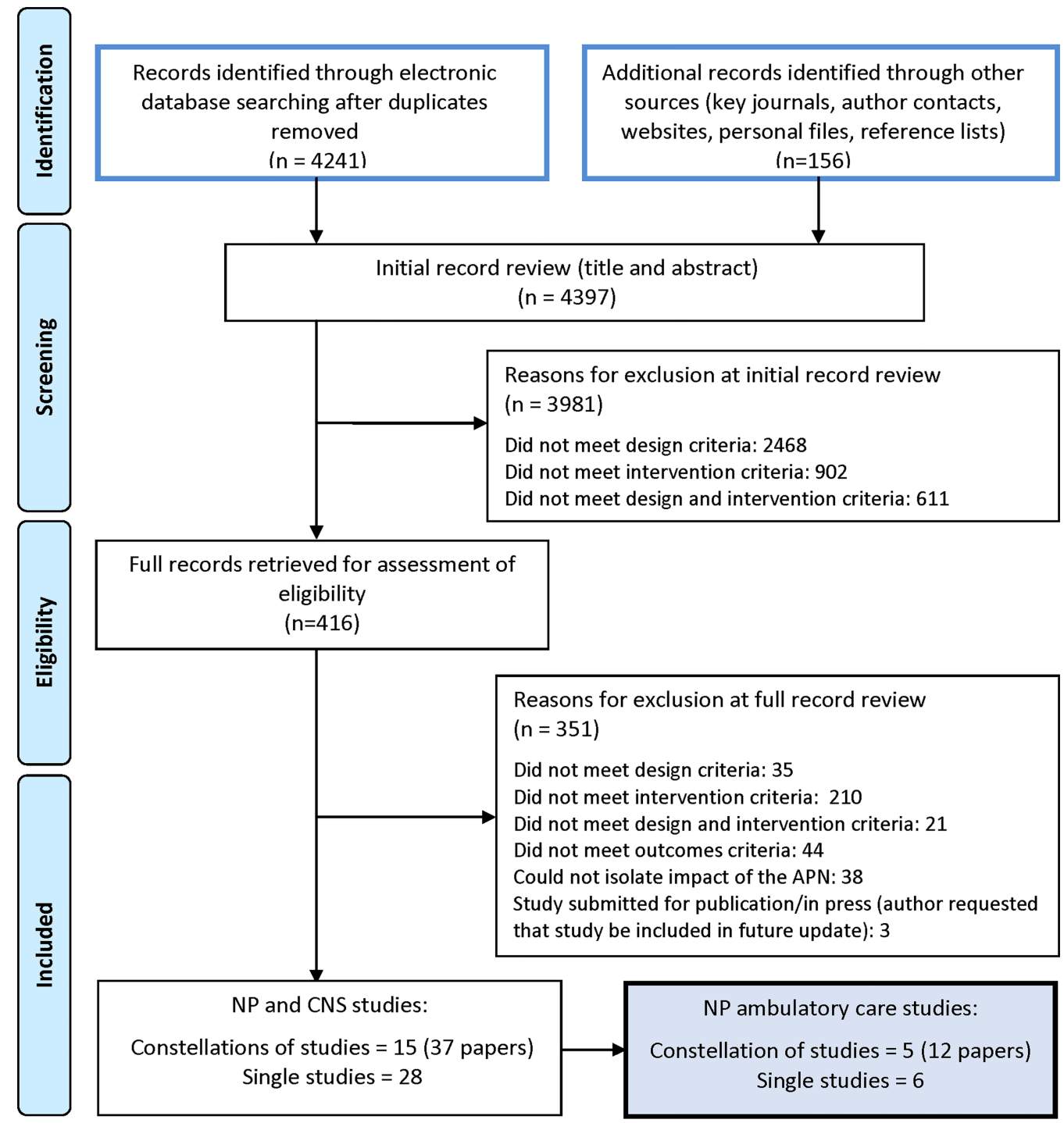

Figure 1 Identification and screening of relevant studies. CNS, clinical nurse specialist; NP, nurse practitioner. Note: Adapted from Moher D, Liberati A, Tetzlaff J, Altman DG, et al. Preferred reporting items for systematic reviews and meta-analyses: The PRISMA statement. BMJ 2009:339:b2535.

potential risk of bias, inconsistency in results, indirectness of evidence, imprecision of results or high probability of publication bias.

\section{Data analysis}

Studies were separated into three groups: (1) alternative provider role in ambulatory primary care; (2) alternative provider role in ambulatory specialised care; and (3) complementary provider role in ambulatory specialised care (none of the studies evaluated the complementary provider role in primary care). All findings were tabulated separately by outcome with corresponding GRADE quality ratings within these groups. If outcomes were sufficiently similar, we combined data in a meta-analysis. For continuous outcome variables, we calculated a weighted mean difference with a 95\% CI. For dichotomous outcomes, we calculated a pooled risk ratio. Given the small number of studies eligible for pooling, we used a fixed-effects model. We investigated statistical heterogeneity by visual inspection of the forest plots, applying the $\chi^{2}$ test for homogeneity and calculating the $\mathrm{I}^{2}$ statistic. $^{16}$

\section{RESULTS}

Eleven trials of nurse practitioners in primary and specialised ambulatory care met our inclusion criteria (figure 1). The studies were conducted in USA, UK, or the Netherlands, and most were published in the year 2000 or later. Table 1 provides a brief overview of each study (see online supplemental file 1 for more detail).

\section{Alternative provider nurse practitioner role in ambulatory primary care}

Four non-inferiority trials assessed whether nurse practitioners in alternative provider primary care roles could function at least at the level of physician comparators, 
Table 1 Characteristics of included studies ( $N=11)$

\begin{tabular}{|c|c|c|c|c|c|c|c|}
\hline $\begin{array}{l}\text { Author, year, } \\
\text { country }\end{array}$ & $\begin{array}{l}\text { Study } \\
\text { objective }\end{array}$ & $\begin{array}{l}\text { Study } \\
\text { setting }\end{array}$ & Participants & Comparison groups & Intervention & $\begin{array}{l}\text { Length of } \\
\text { follow-up }\end{array}$ & $\begin{array}{l}\text { Study } \\
\text { quality* }\end{array}$ \\
\hline \multicolumn{8}{|c|}{ Ambulatory primary care-alternative provider role } \\
\hline $\begin{array}{l}\text { Dierick-van Daele } \\
\text { et al }(2009)^{22} \\
\text { Dierick-van Daele } \\
\text { et al }(2010)^{23} \text { the } \\
\text { Netherlands }\end{array}$ & $\begin{array}{l}\text { Compare NP and GP } \\
\text { care at first point of } \\
\text { contact }\end{array}$ & $\begin{array}{l}15 \text { general } \\
\text { practices in the } \\
\text { Netherlands }\end{array}$ & $\begin{array}{l}1501 \text { patients } \\
\text { (>16 years) attending } \\
\text { an appointment }\end{array}$ & $\begin{array}{l}\text { Alternative NP primary } \\
\text { care }(n=817): 12 \text { NPs; } \\
\text { Control }(n=684): 50 \text { GPs }\end{array}$ & $\begin{array}{l}\text { NPs saw patients at } \\
\text { first point of contact. } \\
\text { GP required to } \\
\text { sign-off all } \\
\text { prescriptions }\end{array}$ & $\begin{array}{l}2 \text { weeks after } \\
\text { appointment }\end{array}$ & $\begin{array}{l}\text { Moderate } \\
\text { risk of bias } \\
\text { QHES: } 62\end{array}$ \\
\hline $\begin{array}{l}\text { Kinnersley et al } \\
(2000)^{24} \text { UK }\end{array}$ & $\begin{array}{l}\text { Compare NP and GP } \\
\text { care for same day } \\
\text { consultations }\end{array}$ & $\begin{array}{l}10 \text { general } \\
\text { practices in UK }\end{array}$ & $\begin{array}{l}1465 \text { patients (all } \\
\text { ages) }\end{array}$ & $\begin{array}{l}\text { Alternative NP primary } \\
\text { care ( } n=652): 10 \mathrm{NPs} ; \\
\text { Control ( } n=716) \text { : GPs } \\
\text { (number not specified) }\end{array}$ & $\begin{array}{l}\text { NPs saw patients at } \\
\text { first point of contact. } \\
\text { GP required to } \\
\text { sign-off all } \\
\text { prescriptions }\end{array}$ & $\begin{array}{l}4 \text { weeks after } \\
\text { appointment }\end{array}$ & $\begin{array}{l}\text { Moderate } \\
\text { risk of bias } \\
\text { QHES: } 34\end{array}$ \\
\hline $\begin{array}{l}\text { Mundinger et al } \\
(2000)^{25} \\
\text { Lenz et al (2002 } \\
\text { and 2004) })^{2627} \\
\text { USA }\end{array}$ & $\begin{array}{l}\text { Compare NP and } \\
\text { physician for ongoing } \\
\text { primary care }\end{array}$ & $\begin{array}{l}5 \text { primary care } \\
\text { clinics in } \\
\text { New York State, } \\
\text { USA }\end{array}$ & $\begin{array}{l}1981 \text { ED or urgent } \\
\text { care adult patients } \\
\text { with no regular source } \\
\text { of care }\end{array}$ & $\begin{array}{l}\text { Alternative NP primary } \\
\text { care }(n=1181): 7 \mathrm{NPs} ; \\
\text { Control }(n=800): 17 \\
\text { physicians }\end{array}$ & $\begin{array}{l}\text { NPs saw patients at } \\
\text { first point of contact } \\
\text { and had same } \\
\text { authority as MDs to } \\
\text { prescribe, consult, } \\
\text { refer, and admit }\end{array}$ & $\begin{array}{l}2 \text { years after } \\
\text { initial } \\
\text { appointment }\end{array}$ & $\begin{array}{l}\text { Low risk } \\
\text { of bias } \\
\text { QHES: } 52\end{array}$ \\
\hline $\begin{array}{l}\text { Venning et al } \\
(2000)^{28} \\
\text { UK }\end{array}$ & $\begin{array}{l}\text { Compare NP and GP } \\
\text { care for same day } \\
\text { consultations }\end{array}$ & $\begin{array}{l}20 \text { general } \\
\text { practices in } \\
\text { England and } \\
\text { Wales, UK }\end{array}$ & $\begin{array}{l}1316 \text { people (all ages) } \\
\text { requesting same day } \\
\text { appointment }\end{array}$ & $\begin{array}{l}\text { Alternative NP primary } \\
\text { care }(n=651): 20 \text { NPs; } \\
\text { Control ( } n=665) \text { : GPs } \\
\text { (number not specified) }\end{array}$ & $\begin{array}{l}\text { NP saw patients at } \\
\text { first point of contact. } \\
\text { GP required to } \\
\text { sign-off all } \\
\text { prescriptions }\end{array}$ & $\begin{array}{l}2 \text { weeks after } \\
\text { appointment }\end{array}$ & $\begin{array}{l}\text { Moderate } \\
\text { risk of } \\
\text { bias } \\
\text { QHES: } 41\end{array}$ \\
\hline \multicolumn{8}{|c|}{ Ambulatory specialised care-alternative provider role } \\
\hline $\begin{array}{l}\text { Limoges-Gonzalez, } \\
\text { et al }(2011)^{31} \\
\text { USA }\end{array}$ & $\begin{array}{l}\text { Compare NP and } \\
\text { gastroenterologist in } \\
\text { screening } \\
\text { colonoscopies }\end{array}$ & $\begin{array}{l}\text { Free-standing } \\
\text { endoscopy } \\
\text { centre in USA }\end{array}$ & $\begin{array}{l}150 \text { English speaking } \\
\text { average risk patients } \\
\text { ( } \geq 50 \text { years) }\end{array}$ & $\begin{array}{l}\text { Alternative NP } \\
\text { specialised care }(n=50) \text { : } \\
1 \mathrm{NP} \text {; Control }(n=100) \text { : } \\
2 \text { gastroenterologists }\end{array}$ & $\begin{array}{l}\text { NP performed the } \\
\text { colonoscopy under } \\
\text { the same conditions } \\
\text { as the doctors }\end{array}$ & $\begin{array}{l}\text { At least } \\
30 \text { mins after } \\
\text { procedure }\end{array}$ & $\begin{array}{l}\text { Low risk } \\
\text { of bias } \\
\text { QHES: } 39\end{array}$ \\
\hline $\begin{array}{l}\text { Schuttelaar et al } \\
(2010)^{29} \\
\text { Schuttelaar et al } \\
(2011)^{30} \\
\text { the Netherlands }\end{array}$ & $\begin{array}{l}\text { Compare NP and } \\
\text { dermatologist care of } \\
\text { children with eczema }\end{array}$ & $\begin{array}{l}\text { Dermatology } \\
\text { outpatient clinic in } \\
\text { the Netherlands }\end{array}$ & $\begin{array}{l}160 \text { children } \\
\text { ( } \leq 16 \text { years) with } \\
\text { atopic dermatitis }\end{array}$ & $\begin{array}{l}\text { Alternative NP } \\
\text { specialised care }(n=81) \text { : } \\
1 \mathrm{NP} \text {; Control }(n=79): 6 \\
\text { dermatologists }\end{array}$ & $\begin{array}{l}\text { NP provided initial } \\
\text { visit, then clinic visit } \\
\text { or telephone call after } \\
2 \text { weeks and follow-up } \\
\text { as needed. } \\
\text { Prescribed } \\
\text { independently }\end{array}$ & $\begin{array}{l}\text { Last follow-up } \\
\text { point at } \\
1 \text { year }\end{array}$ & $\begin{array}{l}\text { Low risk } \\
\text { of bias } \\
\text { QHES: } 80\end{array}$ \\
\hline
\end{tabular}




\begin{tabular}{|c|c|c|c|c|c|c|c|}
\hline $\begin{array}{l}\text { Author, year, } \\
\text { country }\end{array}$ & $\begin{array}{l}\text { Study } \\
\text { objective }\end{array}$ & $\begin{array}{l}\text { Study } \\
\text { setting }\end{array}$ & Participants & Comparison groups & Intervention & $\begin{array}{l}\text { Length of } \\
\text { follow-up }\end{array}$ & $\begin{array}{l}\text { Study } \\
\text { quality* }^{*}\end{array}$ \\
\hline \multirow{2}{*}{\multicolumn{8}{|c|}{$\begin{array}{l}\text { Ambulatory specialised care-complementary provider role } \\
\text { Chronic disease management }\end{array}$}} \\
\hline \multicolumn{7}{|c|}{ Chronic disease management } & \\
\hline $\begin{array}{l}\text { Allen et al (2002) } \\
\text { Paez et al }(2006)^{33} \\
\text { USA }\end{array}$ & $\begin{array}{l}\text { Compare NP case } \\
\text { management to usual } \\
\text { care to decrease } \\
\text { lipids }\end{array}$ & $\begin{array}{l}\text { Outpatient care } \\
\text { Maryland, USA }\end{array}$ & $\begin{array}{l}228 \text { English-speaking } \\
\text { adults with elevated } \\
\text { lipids and coronary } \\
\text { heart disease }\end{array}$ & $\begin{array}{l}\text { Complementary NP } \\
\text { specialised care } \\
(n=115): 1 \text { NP; Control } \\
(n=113): \text { physician }\end{array}$ & $\begin{array}{l}\text { NP had } 1 \text { outpatient } \\
\text { visit } 4-6 \text { weeks } \\
\text { post-discharge to } \\
\text { initiate lipid } \\
\text { management plan } \\
\text { plus follow-up } \\
\text { telephone calls. Had } \\
\text { permission to } \\
\text { prescribe }\end{array}$ & $\begin{array}{l}\text { Last follow-up } \\
\text { point at } 1 \text { year }\end{array}$ & $\begin{array}{l}\text { Low risk } \\
\text { of bias } \\
\text { QHES: } 77\end{array}$ \\
\hline $\begin{array}{l}\text { Krein et al (2004) } \\
\text { USA }\end{array}$ & $\begin{array}{l}\text { Compare NP case } \\
\text { management to usual } \\
\text { care for type } 2 \\
\text { diabetes }\end{array}$ & $\begin{array}{l}2 \text { Department of } \\
\text { veteran affairs } \\
\text { medical centers } \\
\text { in Michigan, USA }\end{array}$ & $\begin{array}{l}246 \text { English speaking } \\
\text { adults ( } \geq 18 \text { years) } \\
\text { with type } 2 \text { diabetes } \\
\text { and poor glycaemic } \\
\text { control }\end{array}$ & $\begin{array}{l}\text { Complementary NP } \\
\text { specialised care } \\
\text { ( } n=123): 2 \text { NP case } \\
\text { managers; Control } \\
\text { ( } n=123) \text { : primary care } \\
\text { physicians }\end{array}$ & $\begin{array}{l}\text { NP monitored and } \\
\text { coordinated care } \\
\text { through telephone } \\
\text { contacts, goal setting, } \\
\text { and treatment } \\
\text { algorithms. } \\
\text { Medication changes } \\
\text { required approval }\end{array}$ & $\begin{array}{l}\text { On } \\
\text { completion of } \\
18 \text { month } \\
\text { intervention }\end{array}$ & $\begin{array}{l}\text { Moderate } \\
\text { risk of } \\
\text { bias } \\
\text { QHES: } 38\end{array}$ \\
\hline $\begin{array}{l}\text { Litaker et al } \\
(2003)^{35} \\
\text { USA }\end{array}$ & $\begin{array}{l}\text { Compare NP-MD } \\
\text { management to usual } \\
\text { MD care for } \\
\text { hypertension and } \\
\text { diabetes }\end{array}$ & $\begin{array}{l}\text { Ambulatory clinic } \\
\text { in } 1000 \text { bed } \\
\text { tertiary hospital } \\
\text { in Ohio, USA }\end{array}$ & $\begin{array}{l}157 \text { adult patients with } \\
\text { mild-moderate } \\
\text { hypertension and } \\
\text { NIDDM }\end{array}$ & $\begin{array}{l}\text { Complementary NP } \\
\text { specialised care ( } n=79): \\
1 \text { NP augmented usual } \\
\text { MD care; Control } \\
(n=78): \text { Usual MD }\end{array}$ & $\begin{array}{l}\text { NP saw patients at } \\
\text { first point of contact } \\
\text { and provided } \\
\text { telephone and } \\
\text { in-office management. } \\
\text { Permission to } \\
\text { prescribe not reported }\end{array}$ & $\begin{array}{l}\text { Last follow-up } \\
\text { point at } \\
1 \text { year }\end{array}$ & $\begin{array}{l}\text { High risk } \\
\text { of bias } \\
\text { QHES: } 39\end{array}$ \\
\hline \multicolumn{8}{|c|}{ Medically unexplained symptoms } \\
\hline $\begin{array}{l}\text { Smith et al } \\
(2006)^{37} \\
\text { Lyles et al (2003) } \\
\text { Luo et al }(2007)^{38} \\
\text { USA }\end{array}$ & $\begin{array}{l}\text { Compare NPs and } \\
\text { standard care for } \\
\text { patients with } \\
\text { medically } \\
\text { unexplained } \\
\text { symptoms }\end{array}$ & $\begin{array}{l}3 \text { staff model } \\
\text { sites of HMO in } \\
\text { Michigan, USA }\end{array}$ & $\begin{array}{l}206 \text { patients } \\
\text { (18-65 years) with } \\
\text { medically unexplained } \\
\text { symptoms and high } \\
\text { utilisation of primary } \\
\text { care services }\end{array}$ & $\begin{array}{l}\text { Complementary NP } \\
\text { specialised care } \\
(n=101): 4 \text { certified } \\
\text { NPs; Control }(n=105) \text { : } \\
21 \text { HMO physicians }\end{array}$ & $\begin{array}{l}\text { NP coordinated and } \\
\text { managed care over a } \\
\text { minimum of } 12 \\
\text { scheduled visits over } \\
\text { a year and telephone } \\
\text { contact between visits }\end{array}$ & $\begin{array}{l}\text { Last follow-up } \\
\text { point at } \\
1 \text { year }\end{array}$ & $\begin{array}{l}\text { Low risk } \\
\text { of bias } \\
\text { QHES: } 27\end{array}$ \\
\hline
\end{tabular}




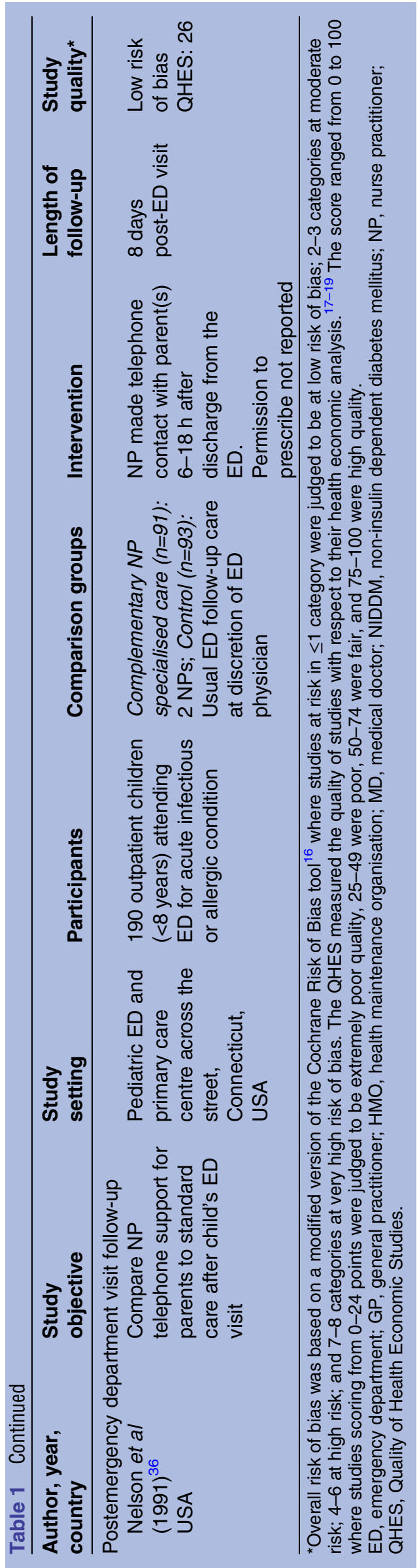

with equal or lower costs. ${ }^{22-28}$ In three trials, the intervention was limited to a single visit with patients seeking same day consultations for common complaints with a follow-up of 2-4 weeks. ${ }^{22} 2428$ The nurse practitioners worked as part of primary care teams alongside general practitioners who were available for consultation and to sign off prescriptions. In contrast, Mundinger et $a l^{25}$ evaluated nurse practitioner care over a 2-year period providing ambulatory care for all adults with oversampling of patients with asthma, diabetes and hypertension. Nurse practitioners independently staffed a primary care clinic and sought off-site physician consultation when needed. The nurse practitioners had full authority to prescribe, refer to specialists and admit patients to hospital.

Based on the Cochrane risk of bias assessment, one trial was at $\operatorname{low}^{25}$ and three at moderate risk of bias. ${ }^{22} 2428$ The Quality of Health Economic Studies scores ranged from a high of $62^{22}$ to a low of $34 .^{24}$ Patient/provider outcomes are reported in a detailed table in online supplemental file 2. Using GRADE, each outcome was assessed as high (HQE), moderate (MQE), low (LQE), or very low quality evidence (VLQE).

In all four studies ${ }^{22} 242528$ nurse practitioner care was at least equivalent to general practitioner care in patient health status outcomes. For patients with hypertension in one study, ${ }^{25}$ the drop in diastolic blood pressure at 6 months was larger in the nurse practitioner group (356 patients) (mean difference: $-3.0 \mathrm{~mm} \mathrm{Hg}$ (95\% CI -5.54 to -0.46$) ; \mathrm{p}=0.04$ ) (LQE). Based on a meta-analysis of two studies in which the nurse practitioners had at least 1 year experience, ${ }^{24} 28$ nurse practitioner care was associated with higher patient satisfaction ( 1515 patients; $\mathrm{I}^{2}=0 \%$ ) (mean difference: $0.15(95 \%$ CI 0.11 to 0.20$) ; \mathrm{p}<0.0001)$ and parent satisfaction (804 parents; $\mathrm{I}^{2}=0 \%$ ) (mean difference: 0.23 (95\% CI 0.16 to 0.30$) ; \mathrm{p}<0.0001$ ) (both 5-point Likert scales; both HQE). In the trial of newly established nurse practitioner roles, ${ }^{22}$ nurse practitioner care was associated with higher patient satisfaction in the subgroup of patients with chronic disease (583 patients) (mean difference: 0.24 (95\% CI 0.05 to 0.43 ); $\mathrm{p}=0.02$ ) (11-point Likert scale; LQE).

With respect to provider outcomes, Kinnersley et $a t^{24}$ found across 10 practices that more patients who consulted a nurse practitioner reported that they had been told the cause of their illness (relative risk (RR) 1.12; 95\% CI 1.06 to $1.19 ; \mathrm{p}=0.0001$ ) (HQE), how to relieve their symptoms (RR 1.27; 95\% CI 1.19 to 1.34; $\mathrm{p}<0.00001$ ) (HQE), and what to do if the problem persisted (RR 1.06; 95\% CI 1.02 to 1.09; $\mathrm{p}=0.002$ ) (HQE).

As table 2 shows, in three studies nurse practitioners had longer consultation times than general practitioners. ${ }^{22} 2428$ Based on moderate quality evidence that included meta-analysis of two studies with over 2500 patients, ${ }^{22} 28$ the mean total consultation time in the nurse practitioner group was $4.1 \mathrm{~min}$ longer per patient (95\% CI 3.7 to $4.5 ; \mathrm{p}<0.0001)$. Heterogeneity was 
Table 2 Health system outcomes-alternative provider role in primary and specialised ambulatory care

\begin{tabular}{|c|c|c|c|c|c|c|c|}
\hline Outcome (outcome measure) & Trials & Population & $\mathbf{N}$ & Effect & $\begin{array}{l}\text { Intervention effect size } \\
\text { ( } 95 \% \mathrm{Cl} \text { ) (NP vs control) }\end{array}$ & $\begin{array}{l}p \text { Value of } \\
\text { effect }^{*}\end{array}$ & $\begin{array}{l}\text { GRADE } \\
\text { quality† }\end{array}$ \\
\hline \multicolumn{8}{|l|}{ Ambulatory primary care } \\
\hline Health services costs (2006 euros) & $\begin{array}{l}\text { Dierick-van Daele et } a l^{23} \\
\text { Venning et } a^{28}\end{array}$ & Primary care & 2689 & MD & $-€ 6.41(-9.28$ to -3.55$)$ & $<0.0001$ & $\mathrm{HIGH}$ \\
\hline Length of consultation & $\begin{array}{l}\text { Dierick-van Daele et } a l^{23} \\
\text { Venning et } a^{28}\end{array}$ & Primary care & 2687 & MD & $4.1 \mathrm{~min}(3.7$ to 4.5$)$ & $<0.0001$ & MOD \\
\hline $\begin{array}{l}\text { Length of consultation } \ddagger \text { (ratios of } \\
\text { consultation time between GP and NP } \\
\text { across } 8 \text { practices) }\end{array}$ & Kinnersley et $a P^{4}$ & Primary care & NR & $\begin{array}{l}\text { Range of } \\
\text { ratios }\end{array}$ & $\begin{array}{l}0.57(0.49 \text { to } 0.67) \text { to } 0.92 \\
(0.7 \text { to } 1.21)\end{array}$ & NR & NA \\
\hline Patient returned for same problem & $\begin{array}{l}\text { Dierick-van Daele et } a l_{;}^{23} \\
\text { Kinnersley et } a l_{;}^{24} \\
\text { Venning et } a \text { P }^{8}\end{array}$ & Primary care & 3482 & $\mathrm{RR}$ & 1.18 (1.06 to 1.32$)$ & 0.002 & $\mathrm{HIGH}$ \\
\hline Care provider asked patient to return & $\begin{array}{l}\text { Dierick-van Daele et } a l^{23} \\
\text { Venning et } a^{28}\end{array}$ & Primary care & 2562 & $\mathrm{RR}$ & $1.32(1.2$ to 1.46$)$ & $<0.0001$ & MOD \\
\hline $\begin{array}{l}\text { Primary care visit within } 1 \text { year of initial } \\
\text { visit }\end{array}$ & Mundinger et $a$ P $^{5}$ & Primary care & 1309 & $\mathrm{RR}$ & $1.01(0.96$ to 1.07$)$ & 0.31 & MOD \\
\hline Referral or specialty visit & $\begin{array}{l}\text { Dierick-van Daele et } a l_{;}^{23} \\
\text { Kinnersley et } a l^{24} \\
\text { Mundinger et } a l^{25}\end{array}$ & Primary care & 4046 & $\mathrm{RR}$ & $0.98(0.87$ to 1.11$)$ & 0.78 & $\mathrm{HIGH}$ \\
\hline Received prescription & $\begin{array}{l}\text { Dierick-van Daele et al; }{ }^{23} \\
\text { Kinnersley et } a l^{24} \\
\text { Venning et } a f^{8}\end{array}$ & Primary care & 4024 & $\mathrm{RR}$ & 0.98 (0.94 to 1.02$)$ & 0.31 & $\mathrm{HIGH}$ \\
\hline Investigations & $\begin{array}{l}\text { Dierick-van Daele et } a l_{;}^{23} \\
\text { Kinnersley et } a l_{;}^{24} \\
\text { Venning et } a^{88}\end{array}$ & Primary care & 4020 & $\mathrm{RR}$ & $1.18(0.94$ to 1.47$)$ & 0.16 & MOD \\
\hline Physical examinations & Venning et $a{ }^{28}$ & Primary care & 1289 & adj OR & $1.76(0.90$ to 3.42$)$ & 0.097 & NA \\
\hline Hospital referrals & Venning et $a{ }^{\text {p }}$ & Primary care & 1292 & adj OR & $0.50(0.16$ to 1.63$)$ & 0.250 & NA \\
\hline Hospitalised within 1 year of initial visit & Mundinger et $a^{25}$ & Primary care & 1309 & $\mathrm{RR}$ & $0.87(0.61$ to 1.23$)$ & 0.42 & LOW \\
\hline $\begin{array}{l}\text { ED or urgent care visit within } 1 \text { year of } \\
\text { initial visit }\end{array}$ & Mundinger et $a^{25}$ & Primary care & 1309 & $\mathrm{RR}$ & $1.01(0.87$ to 1.18$)$ & 0.59 & MOD \\
\hline Number of patient work-days lost & Dierick-van Daele et $a f^{3}$ & Primary care & 1009 & MD & $0.0(-0.04$ to 0.04$)$ & 1.0 & LOW \\
\hline \multicolumn{8}{|l|}{ Ambulatory specialised care } \\
\hline $\begin{array}{l}\text { Total annual societal costs per patient } \\
\text { ( } 2008 \text { euros) }\end{array}$ & Schuttelaar et $a{ }^{\beta 0}$ & $\begin{array}{l}\text { Children with } \\
\text { eczema }\end{array}$ & 147 & MD & $-€ 428(-1040$ to 184$)$ & 0.17 & LOW \\
\hline $\begin{array}{l}\text { Total annual healthcare costs per patient } \\
\text { (2008 euros) }\end{array}$ & Schuttelaar et $\left.a\right|^{\beta 0}$ & $\begin{array}{l}\text { Children with } \\
\text { eczema }\end{array}$ & 147 & MD & $-€ 143(-606$ to 320$)$ & 0.54 & LOW \\
\hline Annual hospital costs (2008 euros) & Schuttelaar et $\left.a\right|^{\beta 0}$ & $\begin{array}{l}\text { Children with } \\
\text { eczema }\end{array}$ & 147 & MD & $-€ 139$ ( -597 to 319$)$ & 0.55 & LOW \\
\hline $\begin{array}{l}\text { Annual community healthcare costs } \\
\text { (2008 euros) }\end{array}$ & Schuttelaar et $a^{\beta 0}$ & $\begin{array}{l}\text { Children with } \\
\text { eczema }\end{array}$ & 147 & MD & $-€ 4(-20$ to 12$)$ & 0.63 & LOW \\
\hline
\end{tabular}




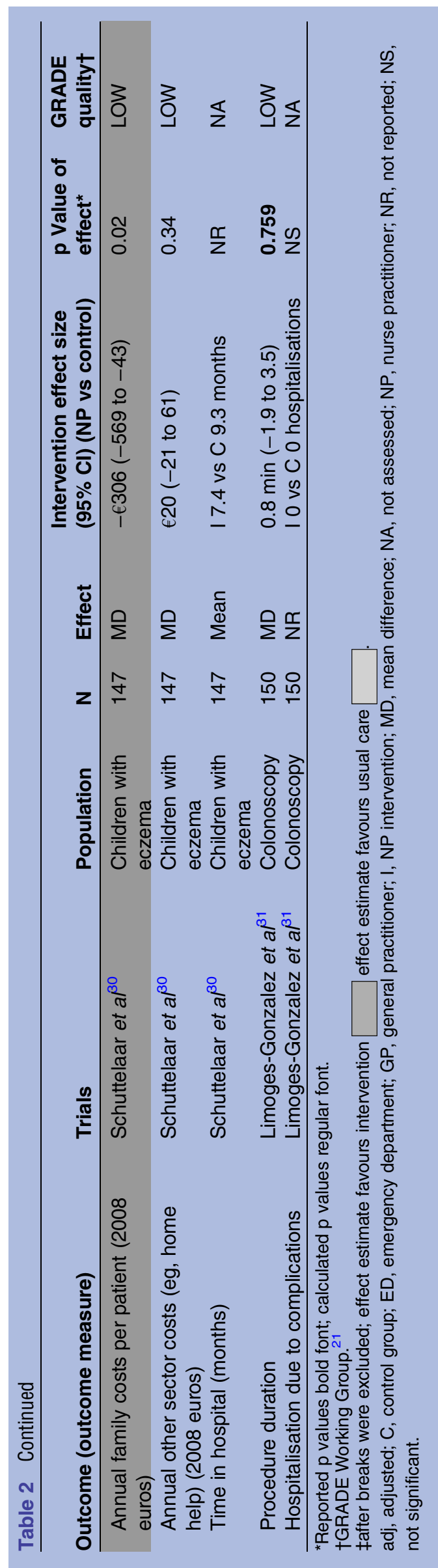

considerable $\left(\mathrm{I}^{2}=97 \%\right)$. A third study found that nurse practitioner consultations were significantly longer in 8 of 10 practices; the ratio of general practitioner to nurse practitioner consultation times varied from 0.57 (95\% CI 0.49 to 0.67$)$ to $0.92(95 \%$ CI 0.7 to 1.21$){ }^{24}$

Two studies reported on the number of patients asked to make a return visit. ${ }^{22}{ }^{28}$ These data were combined, and based on moderate quality evidence, nurse practitioners were more likely to ask patients to return than the general practitioners (2562 patients; $\mathrm{I}^{2}=76 \%$ (RR $1.32,95 \%$ CI 1.20 to 1.46$) ; \mathrm{p}<0.0001)$. The number of patients who made return visits within 2 weeks for the index reason was reported in three trials. ${ }^{22} 2428$ A meta-analysis, including almost 3500 patients $\left(\mathrm{I}^{2}=5 \%\right)$, indicated that more nurse practitioner patients than general practitioner patients made return visits for the same problem ${ }^{22}$ or within 2 weeks $^{28}$ (RR 1.18; 95\% CI 1.06 to $1.32 ; \mathrm{p}=0.002$ ) (HQE). One study examined the number of return visits for any reason over 1 year and found equivalent results (MQE) ${ }^{25}$

Nurse practitioner and general practitioner care were equivalent in terms of the number of patients who were referred (HQE), received a prescription (HQE), had investigations ordered or carried out (MQE), were hospitalised at least once (LQE) or had at least one emergency department or urgent care visit (MQE). Based on a meta-analysis of the only two studies of this role that reported costs (2689 patients) with minimal heterogeneity and high-quality evidence, nurse practitioner care compared to general practitioner care resulted in lower mean health services costs per consultation (mean difference: $-€ 6.41 ; 95 \%$ CI $-€ 9.28$ to $-€ 3.55 ; \mathrm{p}<0.0001)$ (2006 euros). ${ }^{23} 28$ All patient/provider outcomes in these studies were equivalent or better for the nurse practitioner.

\section{Alternative provider nurse practitioner role in ambulatory specialised care}

Two non-inferiority trials assessed whether nurse practitioners in alternative provider roles in specialised ambulatory care could function at least at the level of physician comparators, with equal or lower costs. One focused on care of children with eczema ${ }^{29}{ }^{30}$ and the other on performing screening colonoscopies (table 1). ${ }^{31}$

Based on the Cochrane risk of bias assessment, both trials were at low risk of bias. ${ }^{29} 31$ The Quality of Health Economic Studies score for one trial was $80^{29}$ and for the other $39 .{ }^{31}$ Patient/provider outcomes were assessed using GRADE and are reported in a detailed table in online supplemental file 2 .

One trial compared nurse practitioner and dermatologist care in children with eczema. ${ }^{29}{ }^{30}$ The nurse practitioner used treatment protocols, prescribed independently and had access to a dermatologist if needed. Nurse practitioner care was equivalent to dermatologist care in reducing symptom severity and improving quality of life (LQE). Nurse practitioner care resulted in higher parent satisfaction with care (mean difference: 2.1 (95\% CI 0.34 to 3.86); 
$\mathrm{p}<0.02$ (maximum score 32)) (LQE). With respect to health system outcomes (table 2), the nurse practitioner group had lower mean annual family costs per child (mean difference: $-€ 306$ (95\% CI $-€ 569$ to $-€ 43) ; \mathrm{p}=0.02$ ) (LQE). The trial investigators calculated incremental costeffectiveness ratios for two outcomes: quality of life and parent satisfaction. For the infant and child quality of life outcomes, the nurse practitioner resulted in cost-savings, but was associated with a small reduction in quality of life (incremental cost-effectiveness ratio was $€ 925$ savings per one point less improvement on the 30-point scale infant quality of life measure and $€ 751$ savings per one point less improvement on the 30-point scale child quality of life measure). For parent satisfaction, the nurse practitioner resulted in cost-savings and was associated with improvement in satisfaction (incremental cost-effectiveness ratio was $€ 251$ savings per one point more satisfaction in the nurse practitioner group at 12 months). ${ }^{30}$

One trial compared one nurse practitioner to two gastroenterologists in independently performing screening colonoscopies. ${ }^{31} \mathrm{~A}$ supervising gastroenterologist was immediately available, but not present in the procedure room. Nurse practitioner care was associated with a higher adenoma and advanced neoplasia detection rate (RR 2.47; 95\% CI 1.44 to 4.25; $\mathrm{p}=0.004$ ) (LQE) and higher patient satisfaction scores $(\mathrm{p}=0.042) \quad(\mathrm{MQE})$. Care was equivalent in terms of procedural pain $(\mathrm{LQE})$, patient willingness to repeat the examination (MQE), cecal intubation depth (MQE), immediate complications, procedure duration (LQE) and hospitalisation due to complications.

\section{Complementary provider nurse practitioner role in specialised ambulatory care}

Five superiority trials evaluated nurse practitioners in complementary roles comparing nurse practitioner interventions plus usual care to usual care alone. ${ }^{32-39}$ In all five trials, nurse practitioners were added to usual care in specialised ambulatory settings and were compared to usual care alone (physician-provided care). Four studies limited enrolment to adults with hypercholesterolaemia and coronary heart disease, ${ }^{32}$ type 2 diabetes, ${ }^{34}$ hypertension and type 2 diabetes, ${ }^{35}$ and medically unexplained symptoms. ${ }^{37}$ One study included infants and children presenting to an emergency department with an acute illness (table 1). ${ }^{36}$

Based on the Cochrane risk of bias assessment, three trials were at low, ${ }^{32} 3637$ one at moderate ${ }^{34}$ and one at high risk of bias. ${ }^{35}$ Four of the five trials had Quality of Health Economic Studies scores that were less than $40,{ }^{34-37}$ the lowest score being $26 .^{36}$ One trial had a Quality of Health Economic Studies score of $77 .^{32} 33$ Patient/provider outcomes are reported in detail in online supplemental file 3 .

Three trials compared the addition of nurse practitioner care to usual care (physician-provided care) in chronic disease management. ${ }^{32} 3435$ Of the 26 patient and provider outcomes reported, none favoured usual care, 11 favoured nurse practitioner plus usual care, and 15 were equivalent. Based on a meta-analysis of two studies $^{32} 34$ with 400 patients and moderate heterogeneity $\left(\mathrm{I}^{2}=45 \%\right)$, nurse practitioner plus usual care significantly reduced low-density lipoprotein cholesterol (LDL-C) (mean reduction $11.8 \mathrm{mg} / \mathrm{dL} ; 95 \%$ CI 5.1 to 18.6; $\mathrm{p}=0.0006$ ) (VLQE). Allen $e t a l^{32}$ reported a twofold increase in the proportion of patients with LDL $<100 \mathrm{mg} / \mathrm{dL}$ at 12 months in the nurse practitioner plus usual care group (RR 1.94; 95\% CI 1.44 to 2.61; $\mathrm{p}=0.001$ ) (VLQE). All other outcomes favouring nurse practitioner plus usual care were graded as low quality evidence and included: reduced glycated haemoglobin (pooled data; 2 studies; ${ }^{34} 35366$ patients, $\mathrm{I}^{2}=0 \%$; $0.36 \%$ reduction; $95 \%$ CI $0.04 \%$ to $0.68 \%$; $\mathrm{p}=0.03$ ), reduced fat intake at 1 year (reduction in daily intake $3.7 \%$; $95 \%$ CI $1.7 \%$ to $5.7 \%$; $\mathrm{p}=0.0004),{ }^{32}$ reduced saturated fat intake at 1 year (reduction in daily intake $1.4 \%$; $95 \%$ CI $0.63 \%$ to $2.17 \% ; \mathrm{p}=0.004),{ }^{32}$ reduced cholesterol intake at 1 year (reduction in daily intake $62.5 \mathrm{mg} ; 95 \%$ CI $11.5 \mathrm{mg}$ to $113.5 \mathrm{mg} ; \mathrm{p}=0.017),{ }^{32}$ increased physical activity ( $\geq 6$ metabolically equivalent hours/week: RR 1.56; $95 \%$ CI 1.06 to $2.29 ; \mathrm{p}=0.02),{ }^{32}$ increased medication compliance (RR 1.23; 95\% CI 1.05 to 1.43; $\mathrm{p}=0.004),{ }^{32}$ increased patient satisfaction with care (adjusted $\mathrm{p}=0.04),{ }^{34}$ increased proportion of patients assessing their care provider as at least better than average (RR 1.28; $95 \%$ CI 1.08 to $1.52 ; \mathrm{p}=0.04$ ), ${ }^{34}$ and increased proportion of patients receiving preventive care and education (RRs ranging from 1.05 to 4.41; $\mathrm{p}$ values ranging from 0.06 to $<0.001)$.

As table 3 shows, of nine health system outcomes reported across these studies, one favoured nurse practitioner plus usual care, three favoured usual care and five were equivalent. Based on a meta-analysis of two studies $^{34} 35$ with 373 patients and low heterogeneity $\left(\mathrm{I}^{2}=29 \%\right)$, nurse practitioner plus usual care reduced the number of patients who received care outside the primary care setting over 12-18 months (RR 0.65; 95\% CI 0.44 to $0.94 ; \mathrm{p}=0.02$ ) (LQE). In one study, ${ }^{32} 33$ the incremental cost-effectiveness ratio for nurse practitioner case management over 1 year was $\$ 26.03$ per $\mathrm{mg} / \mathrm{dL}$ reduction in LDL-C and $\$ 39.05$ per per cent reduction in LDL-C (data not shown). The outcomes favouring usual care were reported in one study ${ }^{35}$ and included significantly fewer outpatient visits $(\mathrm{p}<0.001)$, shorter average contact time per patient $(\mathrm{p}<0.001)$ and lower personnel costs $(\mathrm{p}<0.001) \quad(\mathrm{LQE})$.

One study compared nurse practitioner plus usual care to usual care for patients with medically unexplained symptoms and high primary care utilisation; of six patient outcomes, five favoured nurse practitioner plus usual care and one was equivalent (LQE). ${ }^{37-39} \mathrm{At}$ 1 year, more nurse practitioner plus usual care patients had improved mental health status (RR 1.47; 95\% CI 1.05 to 2.07; $\mathrm{p}=0.03)$, less disability $(\mathrm{p}=0.02)$, reduced use of ineffective controlled substance medication by $\geq 25 \%$ (RR 4.92; 95\% CI 2.28 to $10.68 ; \mathrm{p}<0.001$ ), scored 
Table 3 Health system outcomes-complementary provider role in specialised ambulatory care

\begin{tabular}{|c|c|c|c|c|c|c|c|}
\hline Outcome (outcome measure) & Trials & Population & $\mathbf{N}$ & Effect & $\begin{array}{l}\text { Intervention effect size ( } 95 \% \\
\mathrm{CI}) \text { (NP vs control) }\end{array}$ & $\begin{array}{l}\text { p Value of } \\
\text { effect* }^{\star}\end{array}$ & $\begin{array}{l}\text { GRADE } \\
\text { quality† }\end{array}$ \\
\hline \multicolumn{8}{|l|}{$\begin{array}{l}\text { Ambulatory specialised care } \\
\text { Chronic disease management }\end{array}$} \\
\hline Patient received care outside primary care setting & $\begin{array}{l}\text { Krein et } a l^{34} \\
\text { Litaker et } a{ }^{\beta 5}\end{array}$ & $\begin{array}{l}\text { Hypertension, } \\
\text { diabetes }\end{array}$ & 373 & $\mathrm{RR}$ & $0.65(0.44$ to 0.94$)$ & 0.02 & LOW \\
\hline Hospitalised in VA facility & Krein et $a \beta^{\beta 4}$ & Type 2 diabetes & 216 & $\mathrm{RR}$ & $0.81(0.48$ to 1.35$)$ & 0.42 & LOW \\
\hline Primary care visits at VA facility & Krein et $a \beta^{\beta 4}$ & Type 2 diabetes & 216 & MD & $0.0(-1.07$ to 1.07$)$ & 0.39 & LOW \\
\hline $\begin{array}{l}\text { Outpatient management visits for hypertension or } \\
\text { diabetes }\end{array}$ & Litaker et al ${ }^{35}$ & $\begin{array}{l}\text { Hypertension, } \\
\text { diabetes }\end{array}$ & 157 & MedD & More in NP group & $<0.001$ & NA \\
\hline $\begin{array}{l}\text { Total average contact time per patient throughout } \\
\text { year }\end{array}$ & Litaker et $a \beta^{35}$ & $\begin{array}{l}\text { Hypertension, } \\
\text { diabetes }\end{array}$ & 157 & MD & I 180 vs C $85 \mathrm{~min}$ & $<0.001$ & NA \\
\hline $\begin{array}{l}\text { Cost for hypoglycaemic, lipid-lowering, and BP } \\
\text { medications over } 18 \text { months (US\$2000) }\end{array}$ & Krein et $a \beta^{34}$ & Type 2 diabetes & 216 & MD & $\$ 52(-135$ to 239$)$ & 0.70 & LOW \\
\hline $\begin{array}{l}\text { Personnel costs for patient management over } \\
12 \text { months (US\$1995) }\end{array}$ & Litaker et $a^{\beta 5}$ & $\begin{array}{l}\text { Hypertension, } \\
\text { diabetes }\end{array}$ & 157 & MD & $\$ 41$ (22 to 60$)$ & $<0.001$ & LOW \\
\hline Total annual costs $\ddagger$ (USD) & Allen et $a^{\beta 2} 33$ & $\mathrm{CHD}$ & 228 & MD & $\$ 390.50$ & NR & NA \\
\hline Total cost of lipid-lowering medication (USD) & Allen et $a^{\beta 2} 33$ & $\mathrm{CHD}$ & 228 & MD & $\$ 104.48$ & NR & NA \\
\hline \multicolumn{8}{|l|}{ Medically unexplained symptoms } \\
\hline Inpatient hospitalisations over 1 year & Smith et $a{ }^{\beta 7}$ & MUS & 189 & $\mathrm{RR}$ & $1.01(0.44$ to 2.32$)$ & 0.98 & LOW \\
\hline Received care outside of $\mathrm{HMO}$ over 1 year & Smith et $a^{\beta 7}$ & MUS & 189 & $\mathrm{RR}$ & $0.9(0.57$ to 1.43$)$ & 0.66 & LOW \\
\hline $\begin{array}{l}\text { Total cost of health care services after } 1 \text { year (US } \\
\$ 2002 \text { ) }\end{array}$ & Smith et $a l^{\beta 7}$ & MUS & 189 & MD & $-\$ 816$ ( -4131 to 2499$)$ & 0.46 & LOW \\
\hline $\begin{array}{l}\text { Cost of inpatient hospitalisation after } 1 \text { year (US } \\
\$ 2002 \text { ) }\end{array}$ & Smith et $a \beta^{\beta 7}$ & MUS & 189 & MD & $-\$ 1420(-4023$ to 1183$)$ & 0.98 & LOW \\
\hline Cost of any medication after 1 year (US\$2002) & Smith et $a l^{37}$ & MUS & 189 & MD & $\$ 223(-561$ to 1007$)$ & 0.05 & LOW \\
\hline $\begin{array}{l}\text { Cost of antidepressant medication after } 1 \text { year (US } \\
\$ 2002)\end{array}$ & Smith et $a l^{7}$ & MUS & 189 & adj & $\$ 192$ (41 to 342$)$ & 0.012 & LOW \\
\hline \multicolumn{8}{|l|}{ Postemeraency department visit follow-up } \\
\hline $\begin{array}{l}\text { Inappropriate or probably inappropriate use of } \\
\text { follow-up } \delta\end{array}$ & Nelson et $a^{\beta 6}$ & $\begin{array}{l}\text { Children with acute } \\
\text { ED visit }\end{array}$ & 184 & $\mathrm{RR}$ & $0.48(0.23$ to 1.01$)$ & $<0.05$ & LOW \\
\hline Received care elsewhere & Nelson et $a^{\beta 6}$ & $\begin{array}{l}\text { Children with acute } \\
\text { ED visit }\end{array}$ & 184 & $\mathrm{RR}$ & 0.26 (0.06 to 1.17$)$ & 0.08 & LOW \\
\hline Unnecessary revisits to ED & Nelson et $a^{\beta 6}$ & $\begin{array}{l}\text { Children with acute } \\
\text { ED visit }\end{array}$ & 184 & $\mathrm{RR}$ & $1.02(0.15$ to 7.10$)$ & 0.98 & LOW \\
\hline $\begin{array}{l}\text { Failure to follow instructions (subgroup of patients } \\
\text { given instruction) }\end{array}$ & Nelson et $a^{\beta 6}$ & $\begin{array}{l}\text { Children with acute } \\
\text { ED visit }\end{array}$ & 32 & $\mathrm{RR}$ & 0.55 (0.17 to 1.75$)$ & 0.31 & LOW \\
\hline $\begin{array}{l}\text { Missed appointments (subgroup of patients given } \\
\text { appointments) }\end{array}$ & Nelson et $a^{\beta 6}$ & $\begin{array}{l}\text { Children with acute } \\
\text { ED visit }\end{array}$ & 46 & $\mathrm{RR}$ & $0.49(0.15$ to 1.61$)$ & 0.24 & LOW \\
\hline
\end{tabular}

${ }^{\star}$ Reported $\mathrm{p}$ values bold font; calculated $\mathrm{p}$ values regular font.

TGRADE Working Group. ${ }^{21}$

¥Total incremental cost includes NP salary, laboratory tests, and lipid-lowering medication. Effect estimate favours intervention

effect estimate favours usual care

$\S R$ Reported $p$ value calculated using the $\chi^{2}$ test represents a significant difference in favour of NP group although the $95 \% \mathrm{Cl}$ suggests otherwise.

adj, adjusted; BP, blood pressure; C, control group; CHD, coronary heart disease; ED, emergency department; HMO, health maintenance organisation; I, NP intervention group; LDL-C,

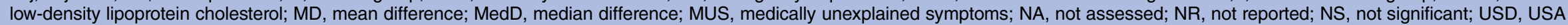

dollar; VA, Veteran's Affairs. 
$\geq 80$ points on all satisfaction scales $(\mathrm{p}<0.01)$ and taken full doses of antidepressant prescriptions (RR 3.46; $95 \%$ CI 2.28 to 5.24; $\mathrm{p}<0.001$ ). Of six health system outcomes, one favoured usual care and five were equivalent (all LQE). The cost of antidepressant medication was higher in the nurse practitioner plus usual care group (increase of US\$192 (2002); 95\% CI $\$ 41$ to $\$ 342 ; \mathrm{p}=0.012$ ) which would be consistent with the increased compliance with full doses described above.

One study ${ }^{36}$ compared nurse practitioner plus usual care to usual care in reducing inappropriate use of emergency department follow-up care by parents of young children. No patient or provider outcomes were reported and of five health system outcomes reported, one favoured nurse practitioner plus usual care and four were equivalent results (all LQE). Fewer nurse practitioner plus usual care parents made inappropriate use of follow-up $(\mathrm{p}<0.05)$.

\section{DISCUSSION}

Our review builds on existing literature ${ }^{8-13}$ by summarising all trials reported since 1980 that include a health system outcome to address the cost-effectiveness of nurse practitioners in primary and specialised ambulatory care. Strengths of our review include a comprehensive search, inclusion of trials that evaluated formally-trained or licensed nurse practitioners, duplicate study selection and quality assessment, quality assessment using Cochrane risk of bias criteria and the Quality of Health Economic Studies instrument, use of GRADE to evaluate outcome-specific quality of evidence, pooling of data wherever possible, and contact with authors for clarification.

Eleven trials evaluated the nurse practitioner in ambulatory care. Six of these trials evaluated alternative nurse practitioner roles, four in primary care and two in specialised care. Five trials evaluated complementary nurse practitioner roles in specialised care. With respect to overall risk of bias, six trials were at low risk (one alternative primary care, ${ }^{25}$ two alternative specialised care ${ }^{2931}$ and three complementary specialised care ca $37^{37}$ ). Four trials were at moderate risk of bias (three alternative primary care 222428 and one complementary specialised care ${ }^{34}$ ). One complementary specialised care trial was at high risk of bias. ${ }^{35}$

When GRADE was applied to individual patient and provider outcomes, the quality of evidence was highest for alternative nurse practitioner roles in primary care; of the 24 outcomes for which GRADE could be applied, 7 were of high, 5 of moderate and 12 of low quality. Of the 10 outcomes for which GRADE could be applied for alternative nurse practitioner roles in specialised ambulatory care, 3 were moderate and 7 low quality. The quality of evidence for patient and provider outcomes was lowest for complementary nurse practitioner roles in specialised ambulatory care; of the 25 outcomes measurable using GRADE, one was of moderate, 16 of low and 8 of very low quality.
When GRADE was applied to individual health systems outcomes, the quality of evidence was highest for alternative nurse practitioner roles in ambulatory primary care; of the 11 outcomes for which GRADE could be applied, 4 were of high, 5 of moderate, and 2 of low quality. Of the seven outcomes for which GRADE could be applied for alternative nurse practitioner roles in specialised ambulatory care, all were low quality. Similarly, all 16 health systems outcomes measurable using GRADE for complementary nurse practitioner roles in specialised ambulatory care were low quality.

While many of the trials in this review were judged to be of high or moderate quality using the Cochrane risk of bias, many of the GRADE assessments of individual outcomes yielded very low or low quality evidence, which may seem contradictory. Most of the downgrading in GRADE occurred because of indirectness when fewer than 10 nurse practitioners contributed to study findings or were novices (both of which reduce generalisability) or when weak surrogate outcomes were used, or because of imprecision stemming from small sample sizes. Neither indirectness nor imprecision are assessed in the Cochrane risk of bias. To address indirectness, future studies should evaluate larger numbers of experienced nurse practitioners and utilise surrogate end points that have a strong association with the clinical end point of interest. ${ }^{40}$ Imprecision occurs when the scatter of data points is so large that there is no meaningful result. To address this, studies should include larger samples to reduce random variability and measure common outcomes that permit data pooling.

Overall, the literature on the cost-effectiveness of nurse practitioners is limited with respect to quantity and quality. It is remarkable that only 11 trials have been conducted that evaluate health systems outcomes of nurse-practitioner-provided care and only 7 measured costs and of these, only 4 assessed costs and outcomes jointly. Appraisal using the Quality of Health Economic Studies instrument found two studies of high quality, one evaluating the alternative nurse practitioner role in specialised ambulatory care ${ }^{29} 30$ and the other the complementary nurse practitioner role in specialised ambulatory care. $^{32} 33$ Two trials evaluating alternative nurse practitioner roles in ambulatory primary care were of fair quality ${ }^{222325}$ and the remaining seven were of poor quality. None of the trials, even those of high quality, used a common outcome, such as quality adjusted life years, which would have allowed comparison of incremental cost-effectiveness ratios across interventions.

Notwithstanding these limitations, as table 4 shows, our review lends some support to the cost-effectiveness of nurse practitioners in the alternative provider role in primary $^{22} 28$ and specialised ${ }^{29}$ ambulatory care. The evidence is strongest for primary care with a meta-analysis of data from two studies (over 2500 patients) showing lower mean health service costs per consultation when compared to general practitioner care. $^{22} 28$ Since meta-analyses were limited to two studies, we could not 
Table 4 Bottom line, overall risk of bias, and quality of health economic analysis

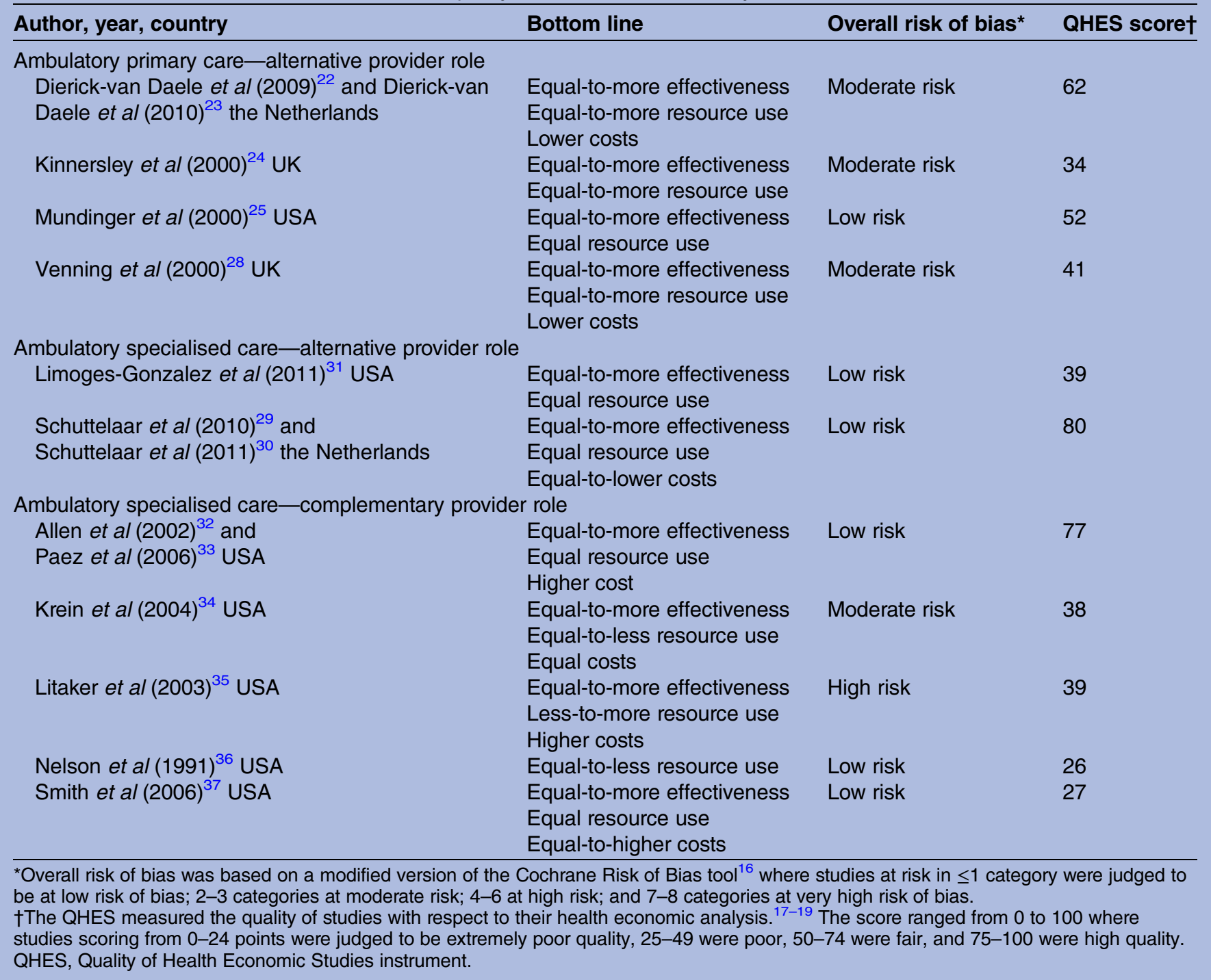

conduct subgroup analyses to explain why heterogeneity was so high for consultation time and return visits. A network analysis indicated that these outcomes may vary by country. Combining data from studies conducted in the Netherlands ${ }^{22}$ and the UK, ${ }^{28}$ meta-analyses indicate that general practitioners in the Netherlands have longer consultation times than UK general practitioners (RR 1.71; 95\% CI 1.19 to 2.23 min longer) and are more likely to ask patients to return (RR 1.67; 95\% CI 1.41 to 1.96$)$.

For the alternative nurse practitioner role, instances of higher resource use in three primary care studies in the UK all relate to length of consultation and/or patient return visits. ${ }^{23} 2428$ This finding was partly explained by nurse practitioners needing to take time to seek a general practitioner to sign prescriptions. ${ }^{22} 2428$ Other contributing factors may have been how appointments were booked, ${ }^{22}$ the considerable difference in years of experience between nurse practitioners and comparator general practitioners ${ }^{22}$ and because nurse practitioners provided more information to patients about their illness and self-management. ${ }^{24}$ Longer consultation times were not observed when nurse practitioners and general practitioners were subject to the same productivity policies, ${ }^{25}$ suggesting that structural factors not reported in the trials, for example, receptionist and office supports, influence performance. While longer consultations increase health resource use, these may improve patient satisfaction ${ }^{24}$ and potentially decrease resource use over time.

With complementary roles, additional costs and resource use are expected given the added nurse practitioner position and the goal to improve outcomes. In this review, half the patient/provider outcomes favoured nurse practitioners suggesting that the role is effective. Not unexpectedly, outcomes, for example, increases in preventive care and patient education, were associated with increased contact time, visits and costs. ${ }^{35}$ Four studies compared costs, but only one assessed costs and outcomes jointly. ${ }^{32} 33$ In this study the incremental costs of nurse case 
management over 1 year based on the nurse's time, lipid-lowering drug costs, and laboratory monitoring costs were $\$ 26 / \mathrm{mg} / \mathrm{dL}$ reduction in LDL-C levels and $\$ 39$ per per cent reduction in LDL-C. Determining if the additional cost is warranted is challenging because of the uncertainty in the strength of the relationship between the surrogate marker of LDL-C and patient-important outcomes such as cardiovascular events.

Finally it must be recognised that determination of cost-effectiveness is fraught with methodological and ethical challenges. For example, the potential cost-savings associated with nurse practitioner alternative primary and specialised ambulatory care provider roles appear to rely on the lower salary of nurse practitioners relative to physicians $^{23} 41$ and the extent to which the nurse practitioner role is autonomous. ${ }^{42}$ This positions nurse practitioners as equally effective healthcare providers who bear the same responsibility and accountability as their physician colleagues, but who are less well compensated. The issue of pay equity, especially for a largely female profession, is undeniable. On the other hand, few studies that measure cost-effectiveness consider the cost implications of the contextual differences in the role expectations of physicians and nurse practitioners or the professional expenses that each is expected to cover, for example, the overhead costs associated with a private business. The complexities are daunting. Yet as the grim consequences of chronic disease and social inequities continue to be revealed, the need for evidence of the cost-effectiveness of nurse practitioners in alternative and complementary roles in ambulatory care has never been greater. Future studies should include a health economist who can guide high quality economic analyses that evaluate quality of life and long-term outcomes such as the prevention of morbidity and mortality (M Lee, DA Marshall. Critical assessment of the cost-effectiveness literature on Advanced Practice Nurses (APNs) and development of a framework for future economic evaluations of APN roles. Unpublished thesis, University of Calgary, 2012).

\section{CONCLUSION}

Nurse practitioners in alternative provider ambulatory primary care roles have equivalent or better patient outcomes than comparators and are potentially cost-saving. Evidence for their cost-effectiveness in alternative provider specialised ambulatory care roles is promising, but limited by the few studies. While some evidence indicates nurse practitioners in complementary provider specialised ambulatory care roles improve patient outcomes, their cost-effectiveness requires further study.

\author{
Author affiliations \\ ${ }^{1}$ School of Nursing, Dalhousie University, Halifax, Nova Scotia, Canada \\ ${ }^{2}$ Health Interventions Research Centre, Ryerson University, Toronto, Ontario, \\ Canada \\ ${ }^{3}$ School of Nursing, McMaster University, Hamilton, Ontario, Canada \\ ${ }^{4}$ Daphne Cockwell School of Nursing, Ryerson University, Toronto, Ontario, \\ Canada \\ ${ }^{5}$ KJResearch, Rosemere, Quebec, Canada
}

${ }^{6}$ Faculty of Nursing, Université de Montreal, Hôpital Maisonneuve-Rosemont Research Centre, Montréal, Quebec, Canada

${ }^{7}$ School of Nursing and Department of Oncology, McMaster University, Hamilton, Ontario, Canada

${ }^{8}$ Department of Community Health Sciences, University of Calgary, Calgary, Alberta, Canada

${ }^{9}$ School of Nursing and Department of Clinical Epidemiology and Biostatistics, McMaster University, Hamilton, Ontario, Canada

Contributors $A D$ and FD had the idea, devised the protocol, obtained funding and contributed to the data extraction and analysis. RC-S conducted searches, obtained and extracted data, and managed the project. KR and DAM contributed to data extraction and analysis. RM-M, PH, KK, NC, DB-L, and SK contributed to the protocol, extracted data and contributed to the analysis. All authors contributed to the paper. AD and RM-M will act as guarantors for the paper.

Funding This work was supported by the Ontario Ministry of Health and Long-Term Care, Nursing Research Fund, Ministry Grant \# 06514 and Office of Nursing Policy, Health Canada and Canadian Foundation for Healthcare Improvement Contract \# 4500244763.

Competing interests $A D$ and $F D$ report a grant from the Ontario Ministry of Health and Long-Term Care and a contract from the Office of Nursing Policy, Health Canada and the Canadian Foundation for Healthcare Improvement to conduct the study. DAM reports she occasionally undertakes ad hoc consulting regarding health economics and outcomes research for a global health economics outcomes organisation called Optum Insight.

Provenance and peer review Not commissioned; externally peer reviewed.

Data sharing statement No additional data are available.

Open Access This is an Open Access article distributed in accordance with the Creative Commons Attribution Non Commercial (CC BY-NC 4.0) license, which permits others to distribute, remix, adapt, build upon this work noncommercially, and license their derivative works on different terms, provided the original work is properly cited and the use is non-commercial. See: http:// creativecommons.org/licenses/by-nc/4.0/

\section{REFERENCES}

1. Mosby's Medical Dictionary. 8th edn. Elsevier, 2009. http://medicaldictionary.thefreedictionary.com/ambulatory+care (accessed 21 Mar 2015).

2. World Health Organization. The world health report 2008-primary health care (now more than ever). World Health Organization. http:// www.who.int/whr/2008/en/ (accessed 21 Mar 2015).

3. Drummond D. Commission on the reform of Ontario's public services. 2012. http://www.fin.gov.on.ca/en/reformcommission/ chapters/report.pdf (accessed 21 Mar 2015).

4. McDonough JE. Health system reform in the United States. Int $J$ Health Policy Manag 2014;2:5-8.

5. Delamaire ML, Lafortune G. Nurses in advanced roles: a description and evaluation of experiences in 12 developed countries. Organization for Economic Cooperation and Development, 2010. http://www.oecd. org/officialdocuments/publicdisplaydocumentpdf/?cote=delsa/hea/wd/ hwp(2010)5\&doclanguage=en (accessed Oct 2014).

6. Cassidy A. Health policy brief: nurse practitioners and primary care. Health Aff 2012. http://www.healthaffairs.org/healthpolicybriefs

7. Donelan K, DesRoches C, Dittus RS, et al. Perspectives of physicians and nurse practitioners on primary care practice. N Engl J Med 2013;368:1898-906.

8. Laurant M, Harmsen M, Wollersheim $\mathrm{H}$, et al. The impact of nonphysician clinicians: do they improve the quality and cost-effectiveness of health care services? Med Care Res Rev 2009;66:36S-89.

9. Spitzer WO, Sackett DL, Sibley JC, et al. The Burlington randomized trial of the nurse practitioner. N Engl J Med 1974;290:251-6.

10. Office of Technology Assessment (OTA). Nurse practitioners, physician assistants, and certified nurse-midwives: a policy analysis (health technology case study 37). Washington DC: US Government Printing Office, 1986.

11. Brown SA, Grimes DE. A meta-analysis of nurse practitioners and nurse midwives in primary care. Nurs Res 1995;44:332-9.

12. Horrocks S, Anderson E, Salisbury C. Systematic review of whether nurse practitioners working in primary care can provide equivalent care to doctors. BMJ 2002;324:819-23. 
13. Newhouse RP, Stanik-Hutt J, White KM, et al. Advanced practice nurse outcomes 1990-2008: a systematic review. Nurs Econ 2011;29:230-50; quiz 251.

14. Berwick DM, Nolan TW, Whittington J. The triple aim: care, health, and cost. Health Aff 2008;27:759-69.

15. Donald F, Kilpatrick K, Reid K, et al. A systematic review of the cost-effectiveness of clinical nurse specialists and nurse practitioners: what is the quality of the evidence? Nurs Res Pract 2014. doi:10.1155/2014/896587

16. Higgins JPT, Green S. Cochrane handbook for systematic reviews of interventions: version 5.1.0. 2011 March. http://handbook.cochrane. org/ (accessed Oct 2014).

17. Chiou CF, Hay JW, Wallace JF, et al. Development and validation of a grading system for the quality of cost-effectiveness studies. Med Care 2003;41:32-44.

18. Ofman JJ, Sullivan SD, Neumann PJ, et al. Examining the value and quality of health economic analyses: implications of utilizing the QHES. J Manag Care Pharm 2003;9:53-61.

19. Spiegel BM, Targownik LE, Kanwal F, et al. The quality of published health economic analyses in digestive diseases: a systematic review and quantitative appraisal. Gastroenterology 2004;127:403-11.

20. Peterson LE, Goodman C, Karnes EK, et al. Assessment of the quality of cost analysis literature in physical therapy. Phys Ther 2009;89:733-55.

21. Guyatt G, Oxman AD, Akl EA, et al. GRADE guidelines: 1. Introduction-GRADE evidence profiles and summary of findings tables. J Clin Epidemiol 2011;64:383-94.

22. Dierick-van Daele AT, Metsemakers JF, Derckx EW, et al. Nurse practitioners substituting for general practitioners: randomized controlled trial. J Adv Nurs 2009;65:391-401.

23. Dierick-van Daele AT, Steuten LM, Metsemakers JF, et al. Economic evaluation of nurse practitioners versus GPs in treating common conditions. Br J Gen Pract 2010;60:e28-35.

24. Kinnersley $\mathrm{P}$, Anderson $\mathrm{E}$, Parry $\mathrm{K}$, et al. Randomised controlled trial of nurse practitioner versus general practitioner care for patients requesting "same day" consultations in primary care. BMJ 2000;320:1043-8.

25. Mundinger MO, Kane RL, Lenz ER, et al. Primary care outcomes in patients treated by nurse practitioners or physicians: a randomized trial. JAMA 2000;283:59-68.

26. Lenz ER, Mundinger MO, Hopkins SC, et al. Diabetes care processes and outcomes in patients treated by nurse practitioners or physicians. Diabetes Educ 2002;28:590-8.

27. Lenz ER, Mundinger MO, Kane RL, et al. Primary care outcomes in patients treated by nurse practitioners or physicians: two-year follow-up. Med Care Res Rev 2004;61:332-51.

28. Venning $P$, Durie $A$, Roland $M$, et al. Randomised controlled trial comparing cost effectiveness of general practitioners and nurse practitioners in primary care. BMJ 2000;320:1048-53.
29. Schuttelaar ML, Vermeulen KM, Drukker N, et al. A randomized controlled trial in children with eczema: nurse practitioner vs. dermatologist. Br J Dermatol 2010;162:162-70.

30. Schuttelaar ML, Vermeulen KM, Coenraads PJ. Costs and cost-effectiveness analysis of treatment in children with eczema by nurse practitioner vs. dermatologist: results of a randomized, controlled trial and a review of international costs. Br J Dermatol 2011;165:600-11.

31. Limoges-Gonzalez M, Mann NS, Al-Juburi A, et al. Comparisons of screening colonoscopy performed by a nurse practitioner and gastroenterologists. A single-center randomized controlled trial. Gastroenterol Nurs 2011;34:210-16.

32. Allen JK, Blumenthal RS, Margolis S, et al. Nurse case management of hypercholesterolemia in patients with coronary heart disease: results of a randomized clinical trial. Am Heart $J$ 2002;144:678-86.

33. Paez KA, Allen JK. Cost-effectiveness of nurse practitioner management of hypercholesterolemia following coronary revascularization. J Am Acad Nurse Pract 2006;18:436-44.

34. Krein SL, Klamerus ML, Vijan S, et al. Case management for patients with poorly controlled diabetes: a randomized trial. $A m \mathrm{~J}$ Med 2004;116:732-9.

35. Litaker D, Mion L, Planavsky L, et al. Physician-nurse practitioner teams in chronic disease management: the impact on costs, clinical effectiveness, and patients' perception of care. J Interprof Care 2003;17:223-37.

36. Nelson EW, Van Cleve S, Swartz MK, et al. Improving the use of early follow-up care after emergency department visits.

A randomized trial. Am J Dis Child 1991;145:440-4.

37. Smith RC, Lyles JS, Gardiner JC, et al. Primary care clinicians treat patients with medically unexplained symptoms: a randomized controlled trial. J Gen Intern Med 2006;21:671-7.

38. Luo Z, Goddeeris J, Gardiner JC, et al. Costs of an intervention for primary care patients with medically unexplained symptoms: a randomized controlled trial. Psychiatr Serv 2007;58:1079-86.

39. Lyles JS, Hodges A, Collins C, et al. Using nurse practitioners to implement an intervention in primary care for high-utilizing patients with medically unexplained symptoms. Gen Hosp Psychiatry 2003;25:63-73.

40. DiCenso A, Guyatt G. Surrogate outcomes. In: DiCenso A, Guyatt G Ciliska D, eds. Evidence-based nursing: a guide to clinical practice. St. Louis: Elsevier Mosby, 2005:222-34.

41. Eibner C, Hussey P, Ridgely MS, et al. Controlling health care spending in Massachusetts: an analysis of options. Santa Monica, CA: RAND Corporation, 2009.

42. Hollinghurst S, Horrocks S, Anderson E, et al. Comparing the cost of nurse practitioners and GPs in primary care: modelling economic data from randomised trials. Br J Gen Pract 2006;56:530-5. 